\title{
THEORETICAL FRAMEWORK FOR BUILDING OPTIMAL TRANSPORT TAXATION SYSTEM
}

\begin{abstract}
The purpose of this article is to analyze the theoretical and methodological basis of building an optimal transport taxation system. That includes establishing classification criteria, functions and principles of building the system. The article systematizes economic views on the nature of transport taxes and outlines the genesis of transport taxation. The article substantiates that the genesis of studies on transport taxation involved the development of economic measures of the size of compensation which followed the special-to-general model, that is, from compensation for the use of particular road network facilities to compensation for the entirety of negative externalities and the use of the whole road network. The article systemizes functions of transport taxation and analyses its two main functions: fiscal and regulatory ones. The article rationalizes that the regulatory function in transport taxation is equally significant. The article analyzes negative external effects resulting from accelerated growth in car ownership. In addition, it substantiates that pure public benefits relating to motor vehicle use tend to transform into mixed benefits in the course of mass car ownership, which, in turn, remain non-excludable, but become rivalrous in consumption. The work presents an original classification of transport taxes based on the main classification criteria. Transport taxes are classified based on types and designation of transport payments, stages of the life cycle of a motor vehicle, the way the tax is levied, the influence it has on the intensity of car use and the purpose of revenue spending. The work offers a system of principles of optimal transport taxation consisting of well-known and new ones. The article further develops the benefit principle in transport taxation as well as the social optimum principle. In addition, it provides definitions for original principles identified by the author: the principle of comprehensiveness, the principle of differentiation, the principle of payment collection at time of service, and the principle of designation.
\end{abstract}

KEYWORDS. Transport taxation; taxes; fees; para-fiscal taxes; classification; function; principles of optimal taxation.

Ю. В. Леонтьева

Уральский федеральный университет им. первого Президента России Б. Н. Ельијина, Екатеринбург, Россия

И.А. Майбуров

Уральский федеральный университет им. Первого Президента России Б. Н. Ельцина, Екатеринбург, Россия; Дальневосточный федеральный университет, Владивосток, Россия

\section{ТЕОРЕТИЧЕСКИЕ АСПЕКТЫ ПОСТРОЕНИЯ ОПТИМАЯЬНОЙ СИСТЕМЫ ТРАНСПОРТНОГО НАИОГООБЛОЖЕНИЯ}

АНнОТАЦИя. Целью данной статьи является анализ теоретико-методологиче-
ских основ построения оптимальной системы транспортного налогообложения
с выделением классификационных признаков, функций и принципов постро- 
ения такой системы. В работе систематизированы экономические воззрения на природу транспортных налогов и представлен генезис транспортного налогообложения. Аргументируется, что генезис исследований в области транспортного налогообложения состоял в развитии экономических обоснований величин компенсаций, развивавшихся по логике от частного к общему, т. е. от компенсации за пользование отдельными объектами дорожно-транспортной сети до обоснования компенсации совокупности всех отрицательных экстерналий и всей дорожно-транспортной сети. Систематизируются функции транспортного налогообложения, проводится анализ двух основных функций: фискальной и регулирующей. Доказывается, что регулирующая функция в транспортном налогообложении является паритетно значимой, анализируются отрицательные внешние эффекты, связанные с форсированной автомобилизацией населения. Кроме того, обосновывается, что чистые общественные блага, используемые при эксплуатации автотранспорта, в процессе массовой автомобилизации трансформируются в смешанные блага, которые в свою очередь сохраняют свойство неисключаемости, но отличаются конкурентностью в потреблении. В результате исследования разработана оригинальная классификация транспортных налогов по основным классификационным признакам, представлены классификации по видам и характеру транспортных платежей, стадиям жизненного цикла транспортного средства, способу взимания платежа, характеру влияния на интенсивность использования транспортного средства и цели его использования. Предлагается система принципов оптимального транспортного налогообложения, включающая известные и оригинальные принципы, развиваются принцип выгоды в транспортном налогообложении и принцип социального оптимума. Сформулированы оригинальные принципы: комплексности, дифференциации, приближенности платежа к услуге, принцип маркировки.

КЛЮЧЕВЫЕ СЛОВА. Транспортное налогообложение; налоги; сборы; парафискалитеты; классификация; функции; принципы оптимального налогообложения.

\section{Introduction}

The influence of taxes on the economic behavior of individuals and organizations is an undeniable fact. The idea of tax regulation of economic agents' behavior was developed in the works of A. Wagner, F. Quesnay, J. M. Keynes and other economists at the end of the 19th century, is still an essential tool of state social and economic regulation. Moreover, while at the early stages of development the idea was mainly limited to the regulation of distribution and consumption thus influencing economic development, now it encompasses all social, political and economic goals of the state.

Transport is a specific sphere of human activity which requires active and immediate regulation, with the help of tax tools among other things. Moreover, the problem is vital in the sphere of affordable and comfortable motor transport. Nowadays peculiarities of motor transport are determined by two trends which have taken shape in the last two decades. On the one hand, motor transport is an independent sector of national economics (motor transport sector) which aims to satisfy the demand for cargo and passenger transportation. On the other hand, one can see accelerated development of the personal car fleet which aims to satisfy private needs. Both the motor transport sector and the use of private motor transport aim to produce similar useful effects and, as achieving this effect involves the use of the same infrastructure, both private and public transport tend to compete against each other. Growing competition for the use of infrastructure, road network and environment at the first place, results in numerous negative consequences $[1 ; 2]$.

The change in requirements for the level and quality of transport services led to a slump in the transport industry in the late 1990s and at the beginning of the 21st century. Since $1990^{\text {th }}$ the number of private cars has grown fivefold and at present there are 3 cars for every ten citizens. At the same time passenger traffic carried by motor transport dropped threefold and cargo turnover fell by 16 percent. A sharp 
(almost uncontrolled) growth of private car ownership has resulted in increasing traffic congestions, limited space, intensified pollution by mobile sources and higher road accident rates.

One of the reasons for growing competition between private and public transport, and negative consequences of such a competition is, in our opinion, the transport taxation system that has taken shape across the world in the last 20-30 years (it was introduced in Russia 15 years ago).

The purpose of this article is to analyze theoretical and methodological frameworks for building an optimal system of transport taxation and to establish classification criteria, functions and principles of building such a system.

\section{Genesis of theoretical models relating to transport taxes}

The history of transport taxation began in ancient times, road tolls (charges for passage) being the first «transport taxes». The use of roads and bridges called for the formation of specific tools of transport taxation. At that time, it was not the vehicle itself that was taxable, but its use, which involved the use of certain infrastructure. Given the absence of any theoretical substantiation for those mandatory payments, they were perceived as a charge for the use of road infrastructure facilities. Thus, the payment was a compensatory one and was aimed at compensating for the costs of construction and maintaining road infrastructure. The development of transport infrastructure and means of transport led to further development of such fiscal tools and gradual formation of the system of vehicle taxes and other taxes incorporated into this system of mandatory payments at the end of the 19th century [3, p. 228].

Theoretical studies of transport taxation issues and, first and foremost, the determination of the transport tax size, did not begin until the middle of the 19th century. On the one hand, economists strongly criticized road charges that were predominantly chaotic and unsubstantiated for hampering trade. On the other hand, they substantiated the need for a wellorganized road network which would ensure strategic and economic advantages, including those promoting the development of trade. The genesis of theoretical substantiations of transport taxation is shown in Fig. 1.

In the 19th century the French School of Bridges and Roads (École Nationale des Ponts et Chaussées) was the most successful one in substantiating road toll payments. Its representatives (J. Vauban, J. Dupuit, M. Allais et al.) defined a tax as the price of public services that is set in terms of the marginal utility theory. According to them, the tax (or the toll) is an instrument of collecting consumer surplus that contributes to the funding of public infrastructure, while the demand for trips is a function of the size of the charge paid [4; 5]. However, it should be noted that representatives of the French school never applied those approaches to automobile roads and used them exclusively for the estimating of the cost of passing bridges, railways and waterways.

$\begin{aligned} & \text { École Nationale } \\ & \text { des Ponts et } \\ & \text { Chaussées } \\ & \text { (1844, J. Dupuit) }\end{aligned}$
$\begin{aligned} & \text { British school } \\ & \text { of road pricing } \\ & \text { (1920, A. Pigou) }\end{aligned}$
$\begin{aligned} & \text { American school } \\ & \text { of road network } \\ & \text { (1969, W. Vickrey) }\end{aligned}$

Figure 1. Main schools working on the subject of transport taxation 
Active development of the car fleet at the beginning of the 20th century and consequences resulting from its use led to the formation of new methodological approaches to determining the size of transport taxes presented by the British school of road pricing. One of its representatives, A. Pigou [6], suggested that transport taxes should be viewed as a way of internalizing negative externalities that occur in the process of automobile use. In this case, the size of transport taxes should reflect the tax price of the negative external effects so that the car owner pays them his money. Most of those effects are paid for by local governments that have to increase spending on road maintenance services, health care, emergency services and environmental services, etc. It is the implementation of the «user-pays principle» [7]. The studies conducted by this school resulted in equations which make it possible to determine the size of externalities on one route (road).

The approach of American economists became a landmark in determining the size of transport taxes. Studies by W. Vickrey in the second half of the 20th century were aimed at evaluating the total cost of road network use and compensation of externalities. However, unlike French and British schools he made evaluations not for particular infrastructure facilities or road sections but for the entire road network in an urbanized territory. This approach enabled him to offer an economic substantiation of the size of vehicle tax as a function of the vehicle run time. Vickrey's pioneering idea was the substantiation back in the 1960s of the requirement that the total amount of the tax to be paid should be determined based on electronic control of mileage [8].

Each of the abovementioned methodological approaches to transport taxes has a logical substantiation and was used to form different kinds of taxes and mandatory payments associated with motor vehicles.

Thus, the genesis of studies on transport taxation involved the development of economic assessments of compensation amounts which followed the special-to- general model, that is, from compensations for the use of particular road network facilities to compensations for the entirety of all negative externalities and entire road network. It is obvious that a single payment does not compensate all kinds of negative effects and that a system of payments is required.

\section{Analysis of effects relating to accelerated motorization}

Active studies of theoretical substantiation, classification and evaluation of externalities relating to motor transport use were conducted only in the past 30 to 40 years. American and European authors M. Hanson, G. McKenzie, M. Delucci, B. de Borger, I. Mayeres, R. Coase and others have contributed most to the studies [9-11]. Russian economists started to pay attention to the issue of balanced development of motor transport only in the last 10 to 15 years.

As we know, any activity that includes public goods is accompanied by various externalities and internal costs.

Externalities are traditionally understood as factors whose benefits and costs are not reflected in the market price of goods and services, unlike internal costs that are reflected in market prices. Consequently, internal costs are covered by car users themselves, while externalities are paid for by the entire society (local community).

Positive externalities are benefits that are enjoyed by a third-party as a result of an activity of another party without any pay from the former. Economic agents are, therefore, willing to pay for benefiting from positive externalities.

Negative externalities are a loss in the welfare of one party resulting from an activity of another party, without there being any compensation for the losing party. In this case, economic agents are prepared to pay for avoiding negative externalities.

At the same time, the market itself is unable to create a system of marketbased prices that would encourage producers of negative externalities to reduce their impact, and consumers of positive 
externalities to pay for the positive external effects. Internalization of externalities make it possible to remedy this inability of the market reflect the occurring effects in pricing. Internalization of externalities is the process of incorporating externalities into the market mechanism of production that provides for their conversion into internal (private) costs that are accounted for in prices. This process is sometimes referred to as correction of externalities.

The concept of externalities was first developed by Arthur Pigou [6]. He theoretically proved that resources are not distributed efficiently in the presence of negative externalities. Consequently, the state has to intervene to solve the problem of internalizing externalities. Such intervention involves imposing a tax that is set equal to the negative externalities. Under Piguo's concept, externalities are internalized through taxation.

R. Coase [9] approached the internalization of externalities from a new angle. He proved a theorem stating that any externality can be internalized through the allocation of property rights. In this case, the inability of the market to factor externalities into prices is circumvented through the allocation of property rights to economic agents with the possibility of their further exchange. Externalities are, therefore, internalized through the allocation of property rights without any further involvement of the state.

The Coase theorem has found its implementation in secondary markets of emissions permits. At the same time, the practical applications of the Coase theorem are limited and the internalization of externalities proves impossible with intervention from the state [12].

The operation of motor transport involves the use of two major types of public goods: the road network and air. The environment as a pure public good used to be considered non-excludable and nonrivalrous. But with the development of technology, economics have long been facing the problem of a limited carrying capacity of the environment and the need to limit access to this good.
Roads are a pure public good, too, that was also considered non-excludable and non-rivalrous until vehicle ownership rates reached a certain level. Vehicle ownership expansion here is understood as the process of motor vehicle saturation in a certain territory (region). Rising car ownership has aggravated the problem of traffic congestion. Road construction is lagging behind the growing amount of cars, while major cities have, for the most part, exhausted their resources for road expansion. The need is ripe for limiting access to this public good as well.

It is possible to conclude that the pure public goods that are used for the operation of car transport are transformed into impure goods as car use increases and remain non-excludable, but become rigorous.

Positive externalities of transport are well known. These include labour mobility, fast shipping of goods, interregional cooperation and holiday and recreation opportunities, which leads to higher labour productivity.

At the same time, negative externalities intensify as vehicle ownership expands. The impact is most prominent in big cities where car use increases spontaneously and people continue to prefer private cars to public transport. In such cities, the negative externalities of motor transport start to outpace the positive ones: traffic speed drops because of congestion; road accident rates go up; drivers are less observant of parking regulations; pedestrian and recreational spaces shrink to allow for bigger roads and parking lots; air quality gets worse and people's general health deteriorates, and so does motorists' mental health.

Table presents the characteristics of the key negative externalities of car use that need to be corrected through transport tax. It has to be noted that the presented externalities are the ones that are most apparent at a higher rate of car ownership when a considerable part of the population of a territory develops strong automobile dependency [13-15]. 
Characteristics of key negative externalities of excessive automobile use in big cities

\begin{tabular}{|l|l|}
\hline Externality & \multicolumn{1}{|c|}{$\begin{array}{l}\text { Characteristics of externality } \\
\text { uncompensated by car users }\end{array}$} \\
\hline Pollution & $\begin{array}{l}\text { Damage caused by exhaust gases, } \\
\text { fuel evaporations, particle pollu- } \\
\text { tion, costs of ill-health }\end{array}$ \\
\hline $\begin{array}{l}\text { Traffic } \\
\text { jams }\end{array}$ & $\begin{array}{l}\text { Time lost in traffic jams; addi- } \\
\text { tional air emissions in traffic jams } \\
\text { and at lower traffic speeds }\end{array}$ \\
\hline $\begin{array}{l}\text { Road ac- } \\
\text { cidents }\end{array}$ & $\begin{array}{l}\text { Uncompensated damage to } \\
\text { involved drivers; time lost by all } \\
\text { travelers; uncompensated higher } \\
\text { costs of emergency medical care } \\
\text { and of restoring traffic after col- } \\
\text { lision }\end{array}$ \\
\hline $\begin{array}{l}\text { More } \\
\text { space for } \\
\text { parking }\end{array}$ & $\begin{array}{l}\text { Costs of uncompensated use } \\
\text { of pedestrian and recreational } \\
\text { spaces for parking, congested } \\
\text { pedestrian and public transport } \\
\text { traffic, esthetic degradation of } \\
\text { streets and neighborhoods }\end{array}$ \\
\hline $\begin{array}{l}\text { More ur- } \\
\text { ban land } \\
\text { devoted } \\
\text { to roads }\end{array}$ & $\begin{array}{l}\text { Costs of reallocating land in cities } \\
\text { for the sake of road construction, } \\
\text { higher prices of land for housing } \\
\text { construction, higher cost of multi- } \\
\text { level interchange projects }\end{array}$ \\
\hline $\begin{array}{l}\text { Noise pol- } \\
\text { lution }\end{array}$ & $\begin{array}{l}\text { Costs of building roadside noise } \\
\text { barrier; costs of ill-health and } \\
\text { increased irritability }\end{array}$ \\
\hline $\begin{array}{l}\text { Costs of unscheduled road sur- } \\
\text { face repairs due to intense traffic, } \\
\text { time lost by all travelers because } \\
\text { of road closures }\end{array}$ \\
\hline toar
\end{tabular}

\section{Classification of transport taxes}

Classification of transport taxes is a substantiated division of transport taxes, fees and other mandatory payments into groups based on a certain distinguishing feature that is done for the purposes of systematization and comparison.

Any classification must comply with two important requirements:

1. Any classification must be based on a definite classification criterion.

2. Any classification must serve particular practical or scientific purposes, that is, it must be relevant to the theory and practice of transport taxation.

There are different classifications based on what is liable to tax, the source of taxation and kind of budgets. But we are going to focus on six most relevant classifications of transport taxes (Fig. 2) which are essential for the purposes of analysis and comparison.

1. Classification by type of levy. The system of transport taxation in any country is made up of levies which vary in their legal nature: taxes, excise taxes and duties, non-tax (fiscal) levies, para-fiscal taxes. Such diversity is needed to make the system of transport taxation more flexible as regards the legal regulation and spending of revenue from the levies.

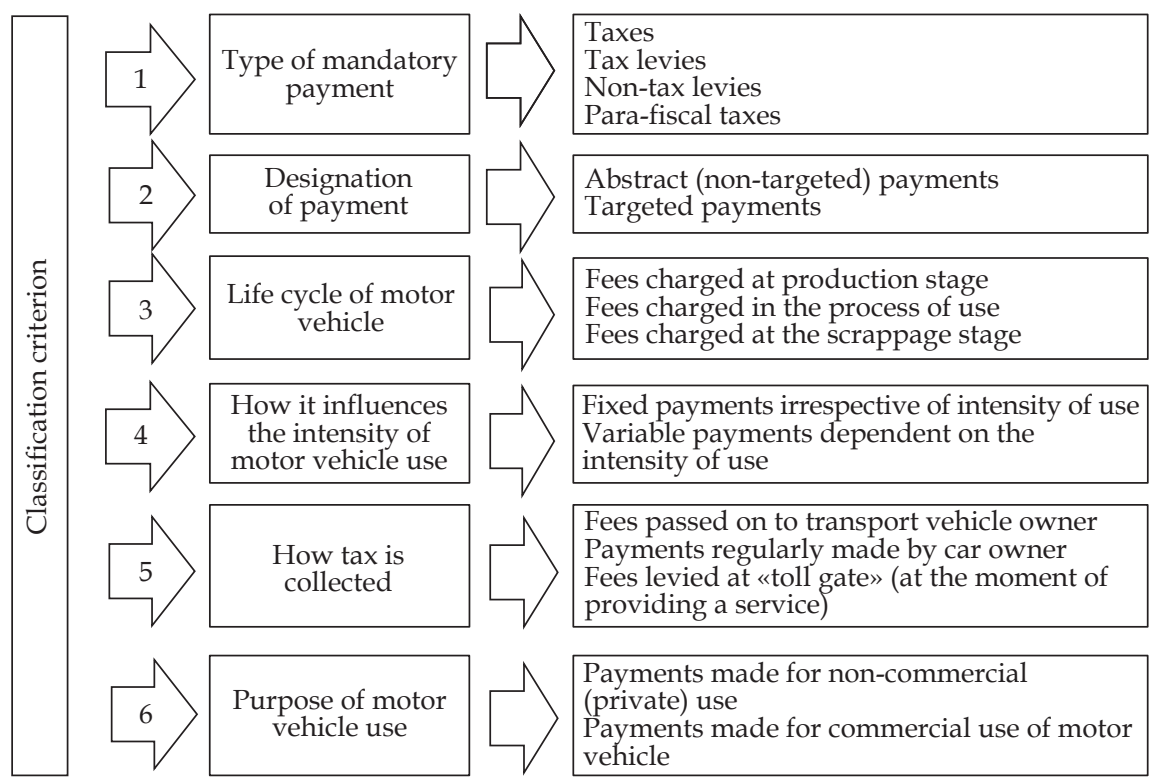

Figure 2. Main classifications of mandatory transport-related payments 
Essentially, the levy (excise) as a tax payment differ from the fiscal levy (duty) as a non-tax one in that they are proportioned differently to the cost of the service (or rights) provided by the state. The general rule says that the size of the fiscal levy has a compensatory role, that is, its size offsets the monetary value of the taxable matter (for example, payments for a negative impact on the environment which offset monetary value of damage caused by airborne pollutants), or provide state with the compensation for the cost of service which was provided (for example, the cost of producing and issuing license plates). Consequently, the size of a fiscal levy should match the size of the benefit got by the payer, or be equal to the cost of service provided to the payer.

To sum up, the enforcement of the state's monopoly on certain actions or services for car owners should be coupled with the payment of a tax, its size doesn't depend on the costs that the state bears. A fiscal levy should be introduced as a charge for a service (a parking fee, a toll for passing a bridge) and its size should correspond to the appropriate costs incurred on the state, or to the special benefit got by the payer; the levy should be designated for a specific purpose and be remitted to extra-budgetary funds. Parafiscal taxes, fulfill their compensatory role as well (truck tolls being an example here). They also have a targeted function, but can be regulated by by-laws and remitted to legal entities of public law or legal entities of private law [16, p. 113].
2. Classification by the nature of levy. The purpose of this classification is to separate revenue from transport taxes according to the objectives of spending.

Abstract (non-targeted) taxes are transport taxes and fees revenue from which is accumulated in a budget, lose their tagging and are spent on general purposes in line with the budget priorities.

Targeted taxes are transport taxes, fees and para-fiscal taxes that are strictly designated for specific expenditures that have to do with road maintenance and the development of the road network and infrastructure.

Giving a designation to payments in transport taxation provides strategic advantages as that makes it possible to form targeted sources of funding for road funds on a long term basis and to make car owners more interested in paying them.

3. Classification by stages of vehicle life cycle. We define the lifecycle of a vehicle as the period of time between its production and its scrappage [17]. Consequently, the period can be divided into three main stages: production, use, and scrappage. We suggest classifying all payments according to each stage of the vehicle lifecycle (Fig. 3).

The classification makes it possible to differentiate tax burdens at each lifecycle stage, shifting the tax load to the stage of use.

4. Classification by impact on the intensity of vehicle use. The classification divides all taxes and levies into two groups.

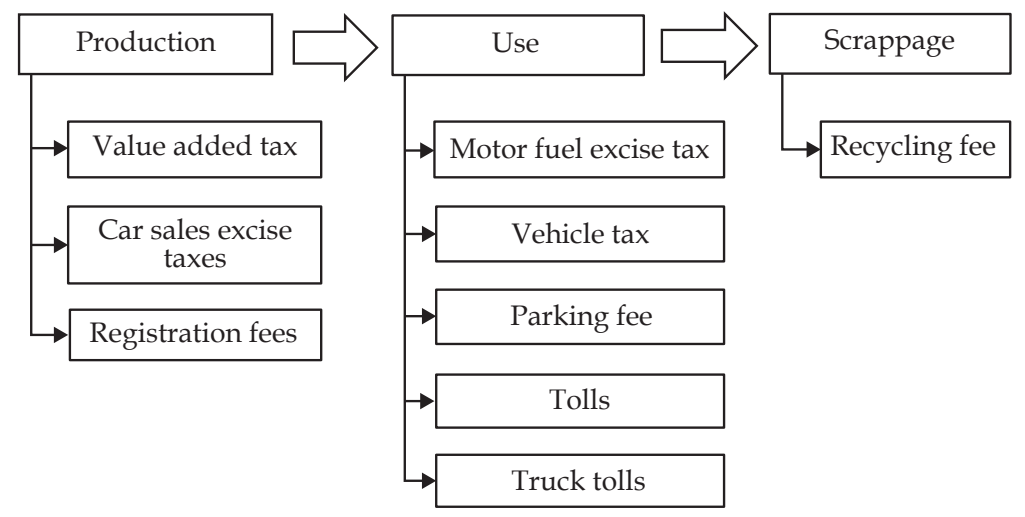

Figure 3. Types of fiscal payments in Russia at various vehicle lifecycle stages 
Fixed taxes. The tax rates are not pegged to the intensity of car use, which means they do not directly involve car owner in the process of negative externalities compensation. Yet their size is a determining factor in the affordability of a car; it influences the level of car ownership in society and the desire (of individuals at the first place) to own a vehicle. High fixed taxes could be used as an instrument of shutting out some people (usually those with low income) from owning a car and, consequently, from driving one. Theory-wise, fixed taxes are essentially Ramsey taxes and ensure certain tax revenues for the government from car owners $[11 ; 13 ; 18]$.

The amount of variable taxes which is determined by the intensity of car use. In this case, the size of transport taxes should reflect the tax price of negative externalities, while each car owner should pay an amount that is equivalent to the total of negative externalities caused by the operation of his/her car. A sophisticated system of variable taxes makes it possible to effectively administer the process of recovering marginal external costs while precisely factoring in all kinds of impact. Foreign studies show that in the case of the absence of fixed transport taxes, the amount of variable taxes is higher than marginal external costs. This makes it possible to also ensure a positive Ramsey component in taxes. From the theoretical perspective, these groups of taxes are Pigouvian taxes [13; 18].

In Russia, fixed transport taxes include value added tax (VAT), stamp fee on the purchase of a vehicle, registration fees, recycling fee, and annually paid vehicle tax. In Russia, variable taxes include fuel excise duties, parking fee, tolls, truck tolls.

5. Classification by method of tax collection. The classification is important for the purposes of analyzing technical arrangements for the system of transport taxation and, most importantly, it is essential for the purposes of functional analysis.

Tax payments that passed on to the owner of the vehicle. Such taxes and duties are paid by the manufacturer (of a motor vehicle, petrol, motor oil, spare parts) and are then shifted onto the consumer as part of the price. The payments are primarily used for the purposes of government revenue collection. Their role as a regulatory factor is insignificant because these taxes are hidden in the price and consumers do not observe them as relevant signals.

Tax payments that are made directly by the owner. Such payments have proper fiscal and regulatory potential. Payments that are contributed by the owner of a motor vehicle on a monthly, quarterly or yearly basis are fully felt by him or her. Their main drawback, however, is that they are inherently fixed and do not encourage owners of motor vehicles to use them less frequently and intensely.

Payments that are collected «at the toll gate» (the moment the service is provided). Such payments have the biggest potential to have a regulatory impact on the behavior of car owners. When the fee is paid exactly at the moment when the consumer gets access to road infrastructure, it may change their travel behavior and even discourage them from using their own car. In this situation the behavioral effect may prove even stronger than the fiscal one (as is the case with the parking fee). The number and application of such payments should inevitably expand along with the growth in car ownership rates.

6. Classification by purpose of vehicle use. This classification is important for the sake of the analysis of tax payments that are associated with private or commercial use of a motor vehicle. Extra taxes should be levied on commercially used vehicles (passenger vehicles, trucks) in addition to taxes that are levied on the use of personal cars. Taxes on financial results serve the purpose. These are taxes on business activities. They are viewed as the tax price that is paid for running a passenger transportation business. In Russia, taxes on financial results include income tax, the single tax on imputed income, and the transport operator license fee.

\section{Functions of transport taxation}

We believe that all payments that form the system of transport taxation should fulfill the following functions: 
1. Fiscal function, i.e. to have a significant distributive and allocative potential. It is about giving the transport taxes the ability to correct the market failure in the area of financial resourcing of construction and repair of roads. The market fails to ensure the development and use of the road network on the principles of individual retribution and equivalence. This task is taken over by the state and is solved by introducing a group of transport taxes. With the help of transport taxes government should accumulate a significant portion of the financial resources of the population and businesses in the budget and target these resources to focus on the development of the road network. Accordingly, the fiscal purpose of transport taxes should ensure the targeted provision of financial resources to road construction funds, and these resources should be sufficient for road construction. In addition, all users of the road network should participate in its funding.

2. Regulatory function, i.e. to have a significant regulatory and behavioral potential. In an aspect of the implementation of this function, transport taxes should encourage economic agents to be environmentally responsible while using motor vehicles. There should be an effort to buy a car of a higher ecological class and use fuel of higher ecological class. Transport taxes should not discourage the desire of economic agents to use vehicles. This rule should be more common in countries where the main mean of transportation is a car.

Through the simultaneous implementation of fiscal and regulatory functions, the transport taxes embody the idea of double dividend, where environmentally oriented behavior of car owners will be accompanied by the formation of stable revenue sources for road construction and environmental protection.

The need to address the regulatory function of the transport fees and the use of fiscal instruments for the promotion of environmentally-oriented behavior of producers and owners of vehicles and related products is recognized by most analysts and researchers [10; 17; 19].

\section{Principles of optimal transport taxation}

When building up a system of transport taxation, both state and car owners would, of course, like their country to have optimal transport taxation.

An optimal system of transport taxation is the one in which interests of all entities and beneficiaries of transport taxation are aligned in the best way possible, while the negative effects of transport taxation are minimized, and the positive ones are maximized.

The theory of optimal taxation addresses the problem of establishing a structure of taxes on various goods (services). The structure of taxes is crucial for generating a set amount of revenue to finance government while reducing inefficiency to a minimum, i.e. minimizing the excess burden of taxation as posited by A. Harberger [20]. Consequently, the criterion of reducing the excess burden of taxation should be the target for designing the transport taxation system. The principles on which the system is built should also be based on the above criterion. We shall outline the principles of an optimal system of transport taxation as follows.

1. Benefit principle. The key principle that transport taxations build on is the benefit principle. The use of transport entails the consumption of two key types of public goods: the road network and the environment. There are, therefore, two things that are critical for identifying private benefits from paying transport taxes. Transport taxation based on the benefit principle requires that taxes are perceived as a tax price for using the road network. The tax rate should represent the tax cost of road construction and maintenance. Transport taxes should also be considered as a way of internalizing negative externalities of car use [6;9]. In this case, the size of transport tax payments should also reflect the tax cost of negative externalities so that the car owner rather than the whole community pays for mitigating them, which is in line with the «user pays» principle [7].

For each car owner, transport tax payments should, therefore, be equal to a sum 
of two components: tax price of using the road network and the tax cost of negative externalities of using the car.

It is much easier to translate the first component of the tax price into practice than the second one. The component reflecting the tax cost of road construction and maintenance for a specific motorist is most accurately represented by excise taxes imposed on the sale of petrol (natural gas) that are transferred to a motorway fund that is dissociated from the treasury. In this case, tax payments are directly linked to the amount of fuel purchased, with its consumption being indicative of the intensity of road use. Consequently, fuel tax is an approximate measure of benefits, and by means of the tax motorists modify their financial contribution to road construction and maintenance.

The measure is approximate because of certain assumptions that are inevitable in the application of fuel tax. Most importantly, it has to be assumed that fuel tax is not entirely targeted and personalized. For example, government can spend tax receipts from a motorist using motorway A on repairing motorway $B$ that is used by another motorist. The assumption produces the problem of equitably splitting tax receipts among road funds (the federal, regional and local ones) that finance interstate, regional and local roads correspondingly. Besides, the tax does not reveal motorists' preferences as regards new road construction.

The second component of the tax price is much harder to employ in practice because the negative externalities are numerous [21]. Specifically, among the negative costs of growing car ownership is recurring traffic congestion, higher road accident rates, growing neglect of parking regulations, the shrinking of pedestrian and recreational spaces to allow for bigger roads and parking lots, increasing air pollution, deterioration of people's health and mental disorders in motorists [22]. These effects are differentiated as per size and territories.

At the same time, it is quite difficult to link all types of negative externalities to a certain fiscal charge. The easiest option would be identify the key negative externalities and associate each of them with a corresponding fiscal charge. It is desirable to make sure that the size of payments charged reflects the specific contribution that each car owner makes to generating negative externalities in a particular territory, which by itself is hard enough [6; 10; 19].

2. Principle of comprehensiveness. An optimal system of transport taxation should be designed as a comprehensive system that includes two different groups of taxes. Its comprehensiveness should show through the inclusion of Pigovian taxes that it takes into account negative externalities, and Ramsey taxes that quantify the benefits of car owners from owning a vehicle. Under the above classification, fixed payments which do not depend on the intensity of car use should follow the Ramsey taxation pattern, while variable payments which depend on the intensity of car use should be based upon the Pigouvian tax model.

The implementation of the principle of incorporating tax price in the size of variable transport taxes proves to be difficult because the number of negative externalities caused by cars grows along with an increase in car ownership. In Table 1 we highlight various types of externalities brought about by motor vehicles. The effects are hard to measure and are differentiated by size and uneven in time and space.

According to European scholars, an optimal system of transport taxation should address the following externalities in order of priority. First of all, it is necessary to deal with the issue of road congestion: when transport-related payments are used for regulating the demand for the road network, it will make it possible to balance the demand against the throughput of the road network. In order to address the task, both variable and fixed taxes could be effectively used as the latter restrict the spread of car ownership.

When the throughput of the road network is sufficient and the problem of road congestion does not exist, variable trans- 
port taxes could be used to offset external effects that are associated with the maintenance and management of transport and road infrastructure, to fund emergency services, to prevent airborne and noise pollution, etc.

3. Differentiation principle. Under Harberger's formula, the excess burden of taxation increases proportionately to the price elasticity of either supply or demand for a good or service. This means that if two goods or services are both taxed at the same rate, the one with higher price elasticity of demand will bear a heavier excess burden of taxation [20]. This rule must be taken into account when introducing differentiated rates of fixed and variable taxes in different areas.

The price elasticity of demand for transportation goods and services is rather high in the case when the area has a well-developed public transport network. In this situation a hike in transport taxes leads to lower demand for trips by car and a considerable increase in the demand for public transport services. The excess burden of taxation will be minimal in the case of a well-developed public transport network. If public transport is uncompetitive in terms of price and quality of services, the price elasticity of demand for transportation goods and services will decrease considerably. In this case, situation occurs when an increase in transport taxes will not bring down the intensity of car use, while the overall excess burden of taxation will increase [13; 23].

4. Principle of payment collection at time of service. The point of payment collection should be as close as possible to the place where externalities occur, that is, it should be as close as possible to the location where transport infrastructure is. This idea serves as a major aspect of the optimization of the variable component of transport taxes. It sends the right price signals to car users who adjust their behavior, trying to reduce costs of car use as much as possible. The system of variable transport taxes can therefore encourage car owner to use his or her car (or discourage them from doing so) during certain time periods and in certain areas. If it is necessary to increase the discouragement effect on car owners, the number of payments charged at the time of service («at the toll gate») should grow. If car owners do not have to pay anything at the time of service, they develop a neutral attitude to the intensity of vehicle use, which makes the population of the area more cars dependent.

5. Principle of designation. A growing tax burden can cause discontent among car owners. It has to be noted that revenue from transport taxes must be spent exclusively on transport-related purposes. When designating transport taxes to a specific purpose it is extremely important to make sure that they are strictly assigned to a specific local government budget. Fixed part of transport taxes can be remitted to federal road funds, while the variable part should be a source of funding for road funds in the area where it is collected and where it shapes public opinion. The spending of money from road funds should be carefully examined from the point of view of technical necessity, priority and public appropriateness.

6. Principle of social optimum. The systemic nature of transport taxes should become an essential prerequisite for building an optimal system of transport taxes. The system of transport taxes consists of separate elements and is at the same time part of a higher tier system of government transport policy. The system of taxes cannot, however, deliver the expected effect if it is not supplemented with an appropriate pricing policy for public transport, a vast and well-developed public transport network, administrative bans and restrictions, etc.

The search for a social optimum in traffic allocation was pioneered by J. G. Wardrop [24]. In 1952, he studied an equilibrium distribution of public and private transport flows within a section of a road network. The point of equilibrium was determined by comparing total disutility (total costs) of all travellers. Wardrop proved that when each road user chooses their preferred means of 
transport, this choice is not socially optimal (Fig. 4).

The passenger flow $P$ moves along the abscissa to the right for the $A$-curve (total expenses of a motorist) and from right to left for the T-curve (total expenses of a public transit passenger). In an ordinary situation, the dependences of aggregate costs on the density of the traffic flow for private and public transport intersect at point $I E$.

The point is the equilibrium point of individuals' preferences. A number of city dwellers $(P A)$ decide to travel by automobile, while another part $(P T)$ of them prefer public transport $(P A>P T)$. The aggregate expenses of all city dwellers are given by the area of the triangle restricted by line $T_{1}$.

V. Vuchic [25] argues that individuals' preferences as to the means of trans- port are pretty stable. Despite any swings of the preferences, urbanites will eventually return to the point of equilibrium. In order to move the equilibrium point to the left towards the social optimum and ensure the stability of the new combination of individuals' preferences it is necessary to simultaneously take a set of measures. It is necessary to implement incentives encouraging the use of public transport. At the same time, it is necessary to adopt measures to discourage the use of private transport.

If any of the sets of measures is adopted in isolation, the structure of the passenger flow will change insignificantly. For example, if incentives are provided for the development of public transport only, the T-curve will shift to the position T1, while equilibrium will move to the point $B$. The time of travel

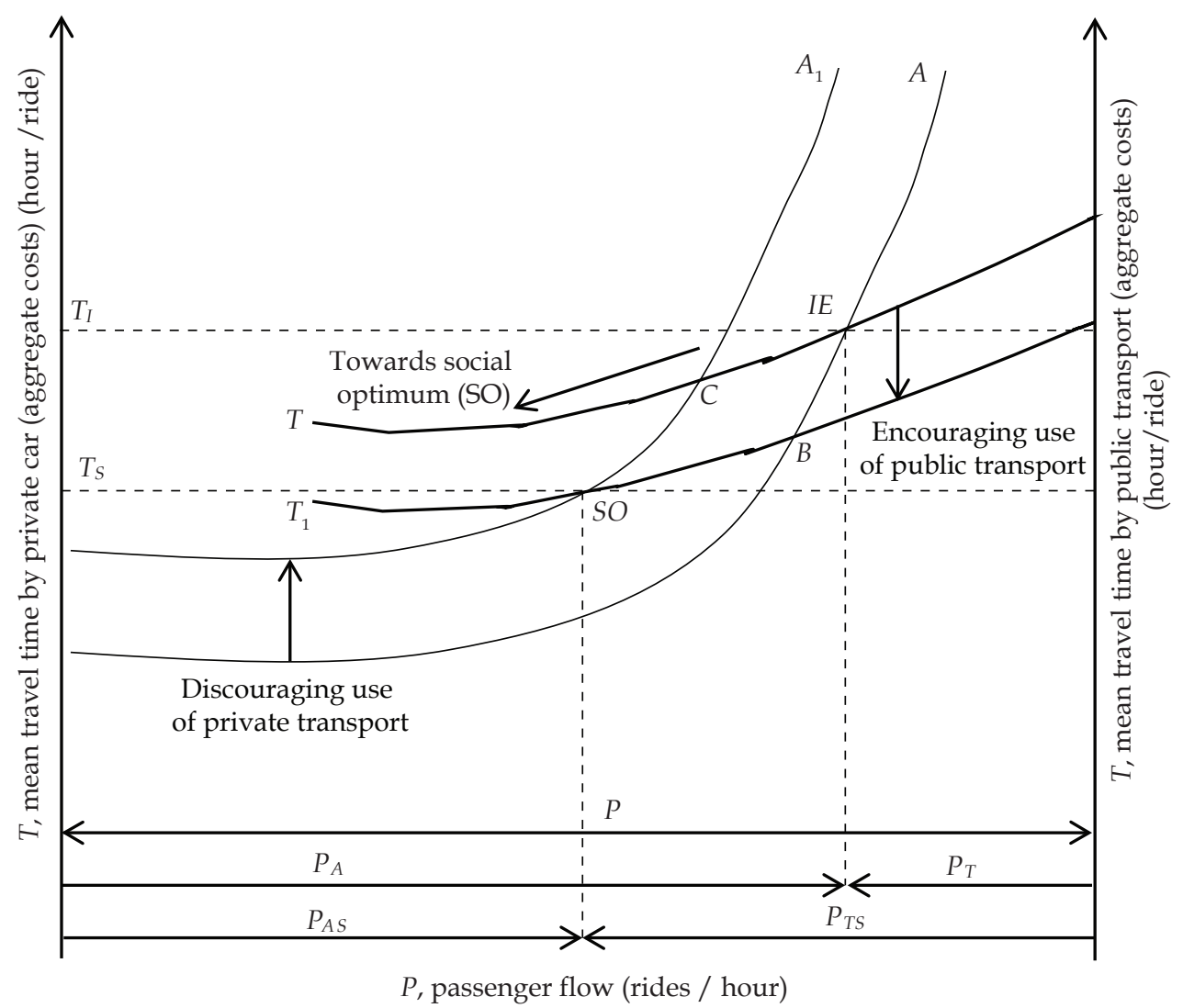

Figure 4. A combination of transport policy measures aimed at shifting equilibrium of individuals' preferences towards the social optimum (SO) 
will change only a little and there will be a certain growth in the number of public transport users. If only measures discouraging the use of private cars are introduced, effects will be insignificant either, with the $A$-curve moving to the position $A_{1}$. Equilibrium will move to the point $C$.

Only combined adoption of all measures of transport policy ensures a shift of the both curves, while equilibrium moves to the social optimum point $(\mathrm{SO})$ that has a completely different set of parameters. There, passenger flows are almost equally divided between public and private transport $(P A \sim P T)$, while aggregate expenses of all urban dwellers who use both private and public transport are significantly reduced. The social optimum can, therefore, be defined as the point $\mathrm{SO}$ where total expenses of all road users are minimized.

A city public transport system that governs itself and functions in accordance with the laws of the market ensures equilibrium of individuals' preferences at the level IE. Such a system is less effective in all cases and generates bigger negative effects than a regulated transport system that provides targeted incentives and discourages various preferences towards the social optimum SO [26].

Specific ways that each urban agglomeration works out in order to shift the curves of preferences for private and public transport towards the social optimum should become the foundation of a long-term transport policy.

\section{Conclusion}

A hyperactive development of the private car fleet that serves personal needs calls for theoretical innovations in the field of transport taxation. Scholarly investigations of optimal transport taxation will prove highly relevant in the mid-term run as theoretical works on the subject are extremely scarce.

We consider the following concepts theoretically proven.

The price of the planned trip will be the key choice factor, so taxes and charges levied upon the trip will have the greatest influence on changing the travel behaviour of car owners. Transport taxes and charges are not essentially homogeneous; they have different impacts on the behaviour of car owners. Similarly to fixed and variable costs, it is useful to divide mandatory transport charges into fixed and variable ones. High rates of variable taxes have the greatest effect on people's current travel behaviour. Urban agglomerations in Europe actively use variable taxes such as fuel excise duties, toll charges, vignettes, congestion charges, distance-based electronically collected tolls, toll lanes, paid parking. In Russia, only fuel excises have found wide application, while paid parking and road tolls are only starting to be introduced. The process, however, is extremely slow and meets strong opposition from car owners. There are no examples to be cited of congestion charges and distance-based road tolls in Russian urban agglomerations. The fiscal burden of fuel excises is insignificant.

Russian urban territory must develop new fiscal instruments that would meet the following fundamental requirements:

- toll revenues must be spent strictly on the objectives of transport policy in the urban agglomeration where the road system was used;

- tolls must be levied according to the distance and be related to the type of the road (federal, regional or municipal);

- the charge should vary depending on the day of the week and the time of the day (the highest during peak hours and a minimal charge during the rest of the day);

- the minimal charge should match the marginal costs of road use, while the maximum rate should also include a surcharge. The surcharge would balance demand for the road network and its capacity.

Russian urban territory must adopt radically new approaches to long-term transport planning. It is necessary to introduce programs of public transport development and rail transit development in the first place. 


\section{References}

1. Mayburov I. A., Leontyeva Y. V. Prospects of regulating car use in Russia by means of taxation. Innovation, Entrepreneurship and Digital Ecosystems. Book proceedings of 9th EuroMed Conference of the EuroMed Academy of Business. University of Warsaw, Digital Economy Lab, 2016, pp. 1249-1255.

2. Mayburov I. A., Leontyeva Y. V. Ecologization of transport taxes as a perspective vector of their improvement. Finansy = Finance, 2014, no. 9, pp. 35-39. (In Russian).

3. Mayburov I. A., Ivanov Yu. B. (eds). Entsiklopediya teoreticheskikh osnov nalogooblozheniya [Encyclopedia of theoretical bases of taxation]. Moscow, Yuniti-Dana Publ., 2016. 503 p.

4. Derycke P.-H. Road pricing - analysis and policies (a historical perspective). Recherches Economiques de Louvain, 1998, vol. 64, iss. 1, pp. 63-74.

5. Lindsey R. Do economists reach a conclusion on road pricing? Econ Journal Watch, 2006, vol. 3, no. 2, pp. 292-379.

6. Pigou A. C. The Economics of Welfare. London, Macmillan and Co. Publ., 1920, 896 p.

7. Newbery D. M., Santos D. G. Road taxes, road user charges and earmarking. Fiscal Studies, 1999, vol. 20, iss. 2, pp. 103-132.

8. Vickrey W. Pricing in Urban and Suburban Transport. American Economic Review, 1963, vol. 52 , iss. 2, pp. 452-465.

9. Coase R. H. The problem of social cost. Journal of Law and Economics, 1960, vol. 3 (1), pp. 1-44.

10. De Borger B. Optimal congestion taxes in a time allocation model. Transportation Research Part B - Methodological, 2011, vol. 45, iss.1, pp. 79-95.

11. De Borger B., Mayeres I. Optimal taxation of car ownership, car use and public transport: Insights derived from a discrete choice numerical optimization model. European Economic Review, 2007, vol. 51, pp. 1177-1204.

12. Baumol W. J. On taxation and the control of externalities. The American Economic Review, 1972, vol. 62, no. 3, pp. 307-322.

13. Litman T. A. Using Road Pricing Revenue: Economic Efficiency and Equity Considerations. Victoria Transport Policy Institute Publ., Canada, 2011. 15 p.

14. Mayburov I. A., Leontyeva Y. V. Transport tax in Russia as a promising tool for reduction of airborne emissions and development of road network. WIT Transactions on Ecology and the Environment. Air Pollution XXIII, 2015, vol. 98, pp. 391-401. DOI: 10.2495/AIR150341.

15. Small K. A., Verhoef E. The Economics of Urban Transportation. Routledge. New York, 2007. $238 \mathrm{p}$.

16. Mayburov I. A., Sokolovskaya A. M. Teoriya nalogooblozheniya. Prodvinutyi kurs [Theory of Taxation. An Advanced Course]. Moscow, Yuniti-Dana Publ., 2011. 591 p.

17. Mayburov I. A., Leontyeva Y. V. Reducing the negative impact of motor transport on the environment: prospects for the use of fiscal instruments in Russia. WIT Transactions on Ecology and the Environment. Energy and Sustainability, 2014, vol. 186, pp. 863-874. DOI: 10.2495/ ESUS140771.

18. Clarke H., Prentice D. A Conceptual Framework for the Reform of Taxes Related to Roads and Transport. Canberra, La Trobe University Publ., 2009. 69 p.

19. Delucchi M. Do motor-vehicle users in the US pay their way? Transportation Research Part A: Policy and Practice, 2007, vol. 41, iss. 10, pp. 982-1003.

20. Harberger A. C. The incidence of the corporation income tax. Journal of Political Economy, 1963, vol. 70, no. 3, pp. 215-240.

21. Litman T. A. Transportation Cost and Benefit Analysis: Techniques, Estimates and Implications. Victoria Transport Policy Institute Publ., Canada, 2003. 19 p.

22. Verhoef E. External effects and social costs of road transport. Transportation Research, 1994, vol. 28a, no. 4, pp. 273-287.

23. Levinson D. M. Equity effects of road pricing: a review. Transport Reviews, 2010, vol. 30, iss. 1 , pp. 33-57.

24. Wardrop J. G. Some theoretical aspects of Road Traffic research. Road Paper № 36. Proceedings of the Institution of Civil Engineers, 1952, vol. 1, pr. 2, pp. 325-362.

25. Vuchic V. R. Urban Public Transportation: Systems and Technology. Englewood Cliffs, NJ, Prentice-Hall, 1981. 673 p.

26. Holden D. J. Wardrop third principle: urban traffic congestion and traffic policy. Journal of Transport Economics and Policy, 1989, vol. 23, no. 3, pp. 239-262. 


\section{Authors}

Yulia V. Leontyeva - PhD in Economics, Associate Professor, Department of Finance and Tax Management, Ural Federal University named after the first President of Russia B. N. Yeltsin, Yekaterinburg, Russia (19 Mira St., 620002, Russia, Yekaterinburg); e-mail: uv.leonteva@mail.ru.

Igor A. Mayburov - Doctor of Economic Sciences, Professor, Head of the Department of Finance and Tax Management, Ural Federal University named after the first President of Russia B. N. Yeltsin, Yekaterinburg, Russia (19 Mira St., 620002, Russia, Yekaterinburg); Chief Researcher of the Department of Finance and Credit, Far Eastern Federal University, 8, Suhanova St., Vladivostok, (8 Suhanova St., 690950, Russia, Vladivostok); e-mail: mayburov.home@gmail.com.

\section{Информация об авторах}

Леонтьева Юлия Владимировна - кандидат экономических наук, доцент, доцент кафедры финансового и налогового менеджмента, Уральский федеральный университет им. первого Президента России Б. Н. Ельцина, г. Екатеринбург, Россия (620002, г. Екатеринбург, ул. Мира, 19); e-mail: uv.leonteva@mail.ru.

Майбуров Игорь Анатольевич - доктор экономических наук, профессор, заведующий кафедрой финансового и налогового менеджмента, Уральский федеральный университет им. первого Президента России Б. Н. Ельцина, г. Екатеринбург, Россия (620002, г. Екатеринбург, ул. Мира, 19); главный научный сотрудник кафедры финансы и кредит, Дальневосточный федеральный университет, г. Владивосток, Россия (690950, г. Владивосток, ул. Суханова, 8); e-mail: mayburov.home@gmail.com. 